\title{
Nuclear Membrane
}

National Human Genome Research Institute (NHGRI)

\section{Source}

National Human Genome Research Institute (NHGRI). Nuclear Membrane.

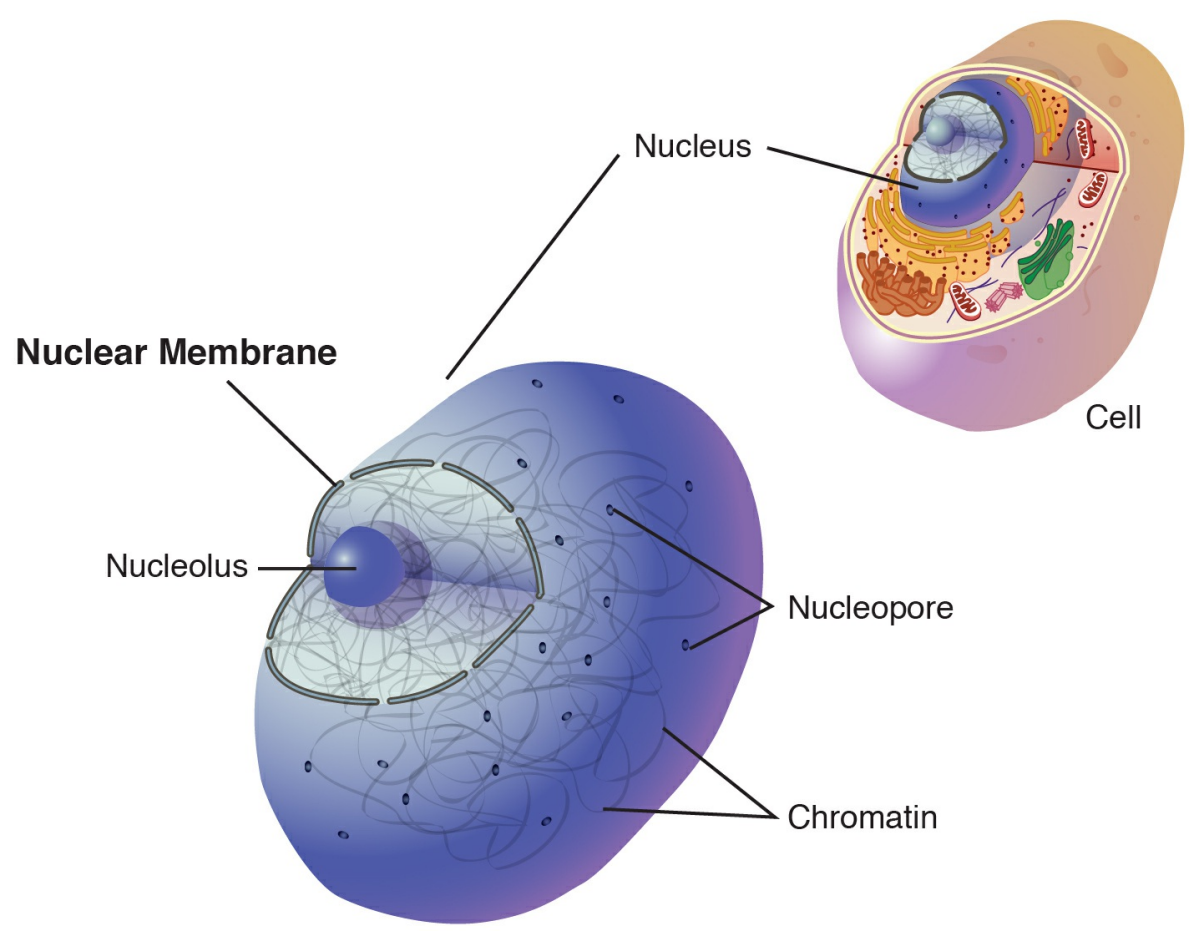

A nuclear membrane is a double membrane that encloses the cell nucleus. It serves to separate the chromosomes from the rest of the cell. The nuclear membrane includes an array of small holes or pores that permit the passage of certain materials, such as nucleic acids and proteins, between the nucleus and cytoplasm. 